\title{
RECENT ADVANCES IN THE STUDY OF BIOCORROSION - AN OVERVIEW
}

\author{
Iwona B. Beech ${ }^{1}$; Christine C. Gaylarde ${ }^{2 *}$ \\ ${ }^{1}$ University of Portsmouth, UK; ${ }^{2}$ Microbiological Resources Center - MIRCEN, Departamento de Solos, \\ Universidade Federal do Rio Grande do Sul - UFRGS. Porto Alegre, RS, Brasil.
}

Submitted: April 07, 1999; Returned to authors for corrections: July 15, 1999; Approved: August 23, 1999.

\section{REVIEW}

\begin{abstract}
Biocorrosion processes at metal surfaces are associated with microorganisms, or the products of their metabolic activities including enzymes, exopolymers, organic and inorganic acids, as well as volatile compounds such as ammonia or hydrogen sulfide. These can affect cathodic and/or anodic reactions, thus altering electrochemistry at the biofilm/metal interface. Various mechanisms of biocorrosion, reflecting the variety of physiological activities carried out by different types of microorganisms, are identified and recent insights into these mechanisms reviewed. Many modern investigations have centered on the microbially-influenced corrosion of ferrous and copper alloys and particular microorganisms of interest have been the sulfate-reducing bacteria and metal (especially manganese)-depositing bacteria. The importance of microbial consortia and the role of extracellular polymeric substances in biocorrosion are emphasized. The contribution to the study of biocorrosion of modern analytical techniques, such as atomic force microscopy, Auger electron, X-ray photoelectron and Mössbauer spectroscopy, attenuated total reflectance Fourier transform infrared spectroscopy and microsensors, is discussed.
\end{abstract}

Key words: copper, corrosion, steel, sulfate-reducing bacteria, surface spectroscopy

\section{INTRODUCTION}

In natural and man-made environments corrosion occurs when materials made of pure metals and/or their mixtures (alloys) undergo a chemical change from the ground state to an ionized species. Corrosion is an electrochemical process consisting of an anodic reaction involving the ionization (oxidation) of the metal (the corrosion reaction), and a cathodic reaction based on the reduction of a chemical species. Many textbooks cover basic corrosion concepts and may be consulted for further details $(16,99)$. These reactions can be influenced by microbial activities, especially when the organisms are in close contact with the metal surface forming a biofilm (Fig. 1). The resulting metal deterioration is known as biocorrosion, or microbially-influenced corrosion (MIC).

Biofilms consist of microbial cells, their extracellular polymeric substances (EPS), which

\footnotetext{
* Corresponding author. Mailing address: MIRCEN, Departamento de Solos, Faculdade de Agronomia, UFRGS, Caixa Postal 776, CEP 90001-970, Porto Alegre, RS, Brasil. E-mail: chrisg@ufrgs.br; iwona.beech@port.ac.uk
} 


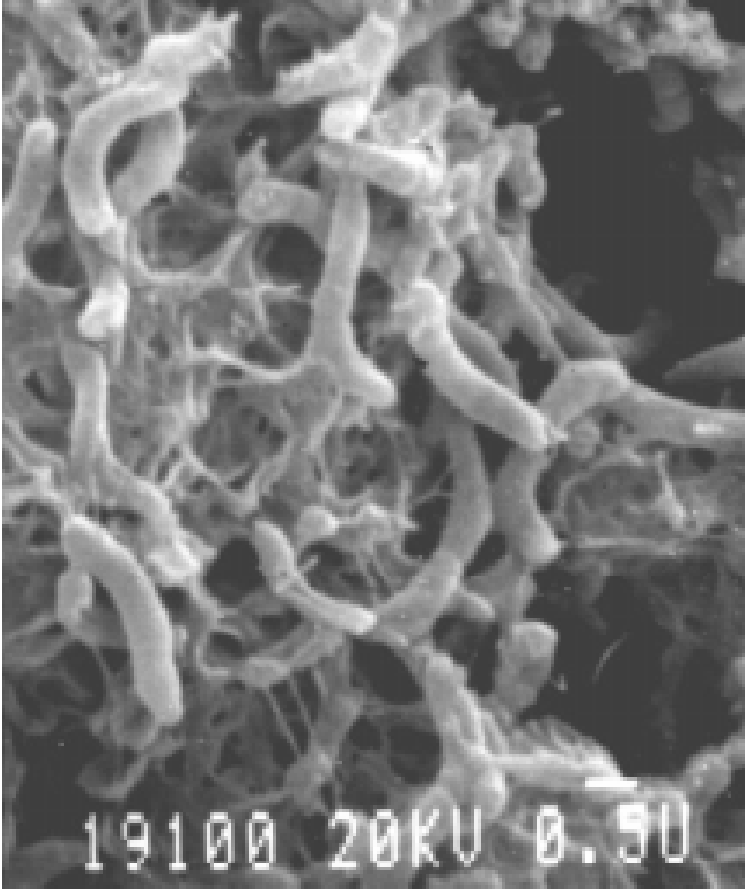

Figure 1 - Biofilm formed by sulfate-reducing bacteria on the surface of mild steel, visualized using SEM.

facilitate irreversible attachment of cells to the surface, inorganic precipitates derived from the bulk aqueous phase and/or corrosion products of the metal substratum. EPS consist of a complex mixture of cellderived polysaccharides, proteins, lipids and nucleic acids. Microorganisms, and/or products of their metabolic activities, e.g. enzymes, exopolymers, organic and inorganic acids, as well as volatile compounds such as ammonia or hydrogen sulfide, can affect cathodic and/or anodic reactions at metal surfaces, thus altering electrochemical processes at the biofilm/metal interface. However, the number of attached microorganisms does not necessarily correlate with the extent of corrosion (6), a fact that has long been known for suspended cells (41). It is the metabolic status of the cells that is believed to be the relevant parameter, but to date no clear consensus has been reached linking specific bacterial metabolic rates to observed corrosion rates.

\section{Economic losses caused by biocorrosion}

There are no official figures for the cost of MIC, but some indication of its importance can be gained from individual companies or sectors of industry.
Escom, the national power utility of South Africa that provides $90 \%$ of power requirements for the country, has detected MIC of carbon steel in cooling water systems in virtually all their power plants. The costs associated with repairs and down time are millions of dollars annually (14). Under-deposit pitting corrosion of heat exchanger tubing in nuclear power generating plants operated by Ontario Hydro of Canada has been estimated to cost the corporation $\$ 300,000$ per unit per day in replacement energy costs (18). Corrosion problems have cost the nuclear utility billions of dollars in replacement costs alone (Jones, 1996). Losses in the oil and gas industry are also substantial; Jack et al. (50) estimated that 34\% of the corrosion damage experienced by one oil company was related to microorganisms. In the 1950s, MIC-related costs of repair and replacement of piping material used in different types of service in the USA were estimated to be around $\$ 0.5-2$ Billion per annum. Booth (15), in the UK, suggested that $50 \%$ of corrosion failures in pipelines involved MIC, while Flemming (40) proposed that approximately $20 \%$ of all corrosion damage to metallic materials is microbially influenced. Replacement costs for biocorroded gas mains in the UK were recently reported to be $£ 250$ Million per annum. Often, financial losses due to damage of equipment by biocorrosion are combined with those resulting from biofouling. While the two phenomena may be associated, they do not cause the same type of damage. The costs associated with MIC usually include the costs of prevention of both MIC and biofouling; since these are based on a limited understanding of the phenomena, they could be underestimated.

\section{Mechanisms of biocorrosion}

MIC does not invoke any new electrochemical mechanisms of corrosion; rather, it is the result of a microbiologically-influenced change that promotes the establishment or maintenance of physicochemical reactions not normally favoured under otherwise similar conditions. Various mechanisms of biocorrosion, which reflect the variety of physiological activities carried out by different types of microorganisms, have been identified; however, it must be remembered that, in nature, these microbial processes do not act in isolation, but in concert with the chemical and electrochemical forces in the particular environment. 


\section{Activities of microorganisms as the driving force for biocorrosion}

Microorganisms implicated in biocorrosion of metals such as iron, copper and aluminium and their alloys are physiologically diverse. Their ability to influence the corrosion of many metals normally considered corrosion resistant, in a variety of environments, makes microorganisms a real threat to the stability of those metals.

The main types of bacteria associated with corrosion failures of cast iron, mild and stainless steel structures are sulfate-reducing bacteria (45), sulfuroxidising bacteria (25), iron-oxidising/reducing bacteria (86 and references therein), manganeseoxidizing bacteria (30), and bacteria secreting organic acids and exopolymers or slime $(25,116)$. These organisms can coexist in naturally occurring biofilms, often forming synergistic communities (consortia) that are able to affect electrochemical processes through co-operative metabolism not seen in the individual species (34). Much recent research activity has centered on the role of "quorum sensing" molecules, such as acylhomoserine lactones, in control of microbial activities in biofilms $(29,83)$, with the aim of using this knowledge to reduce problematical biofilm formation in industry (115).

\section{Sulfate-Reducing Bacteria (SRB)}

SRB are a group of diverse anaerobes which carry out dissimilatory reduction of sulfur compounds such as sulfate, sulfite, thiosulfate and even sulfur itself to sulfide $(4,74)$. Although SRB are often considered to be strictly anaerobic, some genera tolerate oxygen $(1,48)$ and at low dissolved oxygen concentrations certain SRB are able to respire with $\mathrm{Fe}^{3+}$ or even oxygen with hydrogen acting as electron donor (32, 94). Excellent reviews on the ecology and physiology of SRB are available in the literature $(93,117$, Barton, 1995).

Oil, gas and shipping industries are seriously affected by the sulfides generated by SRB (46 and references therein). Biogenic sulfide production leads to health and safety problems, environmental hazards and severe economic losses due to reservoir souring (increased sulfur content) and the corrosion of equipment. Since the beginning of investigations into the effects of SRB on corrosion of cast iron in 1930s, the role of these bacteria in the pitting corrosion of various metals and their alloys in both aquatic and terrestrial environments, under anoxic as well as oxygenated conditions, has been confirmed. Several models have been proposed to explain the mechanisms by which SRB can influence the corrosion of steel (Table 1) and it is clear that sulfate reducing activity is in some way involved. The product of this activity, sulfide, is corrosive; however, chemically-derived sulfide does not have the same degree of aggressivity $(73,79,105)$, demonstrating the importance of bioprocesses and the irrelevance of experiments using abiotic, as opposed to biologically derived compounds. Videla et al. (107) used energy dispersion X-ray analysis, X-ray photoelectron spectroscopy, X-ray diffraction, electron microprobe analysis, scanning electron microscopy and atomic force microscopy to demonstrate that the composition and structure of the sulfide films formed on carbon steel in the presence of the SRB, Desulfovibrio alaskensis, (biotic sulfides) were different from those formed in sterile, sulfide-containing medium (abiotic sulfides). Recent reviews clearly state that one predominant mechanism may not exist in SRB-influenced corrosion and that a number of factors are involved $(47,60)$.

Table 1 - Suggested mechanisms of metal corrosion by SRB.

\begin{tabular}{|c|c|}
\hline Corrosive process/substance & Reference(s) \\
\hline $\begin{array}{l}\text { Cathodic depolarization* } \\
\text { by hydrogenase }\end{array}$ & $\begin{array}{l}\text { von Wolzogen Kühr and van } \\
\text { der Vlugt, 1934; Bryant et al., } \\
1991 \text {. }\end{array}$ \\
\hline Anodic depolarization* & $\begin{array}{l}\text { Salvarezza and Videla, 1984; } \\
\text { Daumas et al., 1988; Crolet, } \\
1992 .\end{array}$ \\
\hline Sulfide & Little et al., 1998. \\
\hline Iron sulfides & King and Wakerley, 1973. \\
\hline A volatile phosphorus compound & Iverson and Ohlson, 1983. \\
\hline Fe-binding exopolymers & $\begin{array}{l}\text { Beech and Cheung, 1995; } \\
\text { Beech et al., 1996, 1998, } 1999 .\end{array}$ \\
\hline $\begin{array}{l}\text { Sulfide-induced stress } \\
\text { corrosion cracking }\end{array}$ & Edyvean et al., 1998. \\
\hline $\begin{array}{l}\text { Hydrogen-induced cracking } \\
\text { or blistering }\end{array}$ & Edyvean et al., 1998. \\
\hline
\end{tabular}

\footnotetext{
* depolarization is an acceleration of the corrosion reaction and may involve removal of cathodic or anodic reactants.
} 
Considerable work has centered on the influence of ferrous ions on SRB action on steel alloys. Obuekwe et al. (86) reported extensive pitting of mild steel when ferrous and sulfide ions were being formed concurrently. When only sulfide was produced, corrosion rates first increased and then declined due to the formation of a protective FeS film. High levels of soluble iron prevented the formation of such protective layers. Moulin et al. (84) demonstrated that high soluble iron levels could lead to high corrosion rates of piling grade carbon steel and Gubner et al. (44) showed that this was linked to a decrease in $\mathrm{pH}$. The hydrogenase of Desulfovibrio vulgaris (Hildenborough) has been shown to be regulated by $\mathrm{Fe}^{2+}$ availability (20), offering yet another mechanism whereby corrosion may be affected, as assessed by Cheung and Beech (23). Thus the influence of iron ions on SRB-influenced corrosion is a complex phenomenon; this was reviewed by Videla et al. (108).

The impact of sulfides on the corrosion of copper alloys has recently received considerable attention. Copper alloys are attacked after only one day in seawater containing $0.01 \mathrm{ppm}$ sulfide. In the presence of sulfide ions, an interstitial cuprous sulfide compound, with the general stoichiometry $\mathrm{Cu}_{2-\mathrm{x}} \mathrm{S}$ $(0<x<1)$, is formed; copper ions migrate through this layer and react with more sulfide. The result can be the production of thick scale (71).

Specific removal of nickel from $90-10$ and 70-30 $\mathrm{Cu}-\mathrm{Ni}$ has been reported in seawater containing SRB $(64,112)$. Spalling of the nickel-enriched region of the metal occurs during exposure to flowing seawater, exposing fresh metal and causing further dissolution of the alloy. Welds also exhibit this type of corrosion in the presence of SRB (63).

SRB can induce corrosion of zinc and lead based alloys. The corrosion product on zinc is reported to be sphalerite (ZnS), while the action of SRB on lead carbonates produces galena $(\mathrm{PbS})$, also found as a corrosion product on lead-tin alloys (71).

\section{Metal-Reducing Bacteria (MRB)}

Microorganisms are known to promote corrosion of iron and its alloys through reactions leading to the dissolution of corrosion-resistant oxide films on the metal surface. This results in the protective passive layers on e.g. stainless steel surfaces being lost or replaced by less stable reduced metal films that allow further corrosion to occur. Despite its widespread occurrence in nature and likely importance to industrial corrosion, bacterial metal reduction has not been seriously considered in corrosion reactions until recently.

Numerous types of bacteria, including those from the genera Pseudomonas (86) and Shewanella (85) are able to carry out manganese and/or iron oxide reduction and have been shown to influence corrosion reactions. It has been demonstrated that in cultures of Shewanella putrefaciens, iron oxide-surface contact was required for bacterial cells to mediate reduction of these metals (85). The rate of reaction depended on the type of oxide film under attack (69).

\section{Metal-Depositing Bacteria (MDB)}

Bacteria of the genera Siderocapsa, Gallionella, Leptothrix, Sphaerotilus, Crenothrix and Clonothrix participate in the biotransformation of oxides of metals such as iron and manganese (43). Irondepositing bacteria (e.g., Gallionella and Leptothrix) oxidize $\mathrm{Fe}^{2+}$, either dissolved in the bulk medium or precipitated on a surface, to $\mathrm{Fe}^{3+}$. Bacteria of the genera given above are also capable of oxidizing manganous ions to manganic ions with concomitant deposition of manganese dioxide (70).

A role in the corrosion of steels has been proposed for sheathed filamentous bacteria detected by microscopy in naturally formed corrosion deposits $(57,75,104)$. These bacteria have been typically associated with formation of tubercles (macroscopic deposits containing microorganisms, inorganic and organic materials) and consequent under-deposit pitting attack on stainless steel. The corrosion resistance of alloys such as stainless steels is due to the formation of a thin passive oxide film. The formation of organic and inorganic deposits by MDB on the oxide surface compromises the stability of this film. Dense accumulations of MDB on the metal surface may thus promote corrosion reactions by the deposition of cathodically-reactive ferric and manganic oxides and the local consumption of oxygen by bacterial respiration in the deposit. However, care must be taken in considering microorganisms in corrosion products to be the causal agent. Some bacteria are known to adhere preferentially to corrosion products and thus will be present in high numbers even when playing no role in the primary corrosion process (72).

MDB have been shown to promote ennoblement of metals (a change to more positive values of pitting 
potential) and pitting corrosion. It has been demonstrated that the formation of a surface biofilm containing the sheath-forming, manganesedepositing bacterium, Leptothrix discophora, resulted in the ennoblement of $316 \mathrm{~L}$ stainless steel (31). The biofilm was proposed to be necessary for deposition and electrical contact of cathodicallyactive $\mathrm{MnO}_{\mathrm{x}}$ at the metal surface so that electron transfer from the metal to the $\mathrm{MnO}_{\mathrm{x}}$ deposit could occur. The resulting ennoblement, observed under laboratory conditions, mimicked the pattern of ennoblement of stainless steels submerged in natural waters. However, the ennoblement produced in the laboratory study was not accompanied by the characteristic pitting corrosion of the metal, demonstrating the limitations of our current understanding of pit initiation and propagation in steels by MDB.

\section{Slime-producing bacteria}

Microorganisms that produce copious quantities of EPS during growth in biofilms have been implicated in localized attack of stainless steels (92). Slime-forming microorganisms that have been recovered from sites of corrosion on stainless steels include Clostridium spp., Flavobacterium spp., Bacillus spp., Desulfovibrio spp., Desulfotomaculum spp. and Pseudomonas spp.

As little as $10 \mathrm{ng} \mathrm{cm}^{-2}$ EPS has been reported to provoke the onset of MIC of stainless steel in natural seawater; cathodic protection of the stainless steel, used to prevent corrosion, actually increased the amount of EPS in the biofilm (97). However, the role of EPS in MIC of stainless steel remains obscure. It has been postulated that they are not sufficient to induce biocorrosion of stainless steel unless aided by the presence of a biocatalyst of oxygen reduction (98), which could be oxido-reductase enzymes entrapped in the biofilm (58). EPS has even been suggested to protect metal surfaces from corrosion. A bacterial consortium consisting of a thermophilic Bacillus sp. and Deleya marina produced metalbinding EPS that reduced the rate of corrosion of carbon steel by $94 \%$ (35). Such a mechanism may be responsible for the protection microorganisms afford to mild steel under certain conditions (102).

A case of corroded copper pipework in a drinking water system involved the presence of a film that stained positive with periodic acid- Schiff's reagent (PAS) and alcian blue, suggesting the presence of acidic polysaccharides (2). Scanning electron microscopy showed that copious amounts of biofilm were associated with the pitted sites (55), with the most severely corroded tubes containing the most well-developed biofilm (76). In another case, chemical analysis of the adherent copper corrosion products recovered from failed copper tube suggested an interaction between the inorganic products and biologically-derived organic molecules. Copper corrosion products were located on top of or within a microbial biofilm layer in direct contact with the bare metal surface in areas where the pipe was perforated $(38,39)$. The biofilm contained linear and/or cross-linked acidic or non-ionic polysaccharides, oligopeptides and $\mathrm{N}$-acetylated derivatives of glucose, mannose and galactose. Corrosion products rich in copper complexes of pyruvate, acetate, and histidine were identified (89). Binding of $\left[\mathrm{Cu}_{2} \mathrm{Cl}_{2}\right]_{\mathrm{n}}^{2-}$ ions in the biofilm suggested a mechanism whereby $\mathrm{Cl}^{-}$sequestration into the pits could promote further ionization of metallic copper (38). Microbiological evaluation of the corrosion deposits showed that while high numbers of bacteria were associated with the pits, the presence of bacteria was not always related to pitting and that the range of cultured bacterial species was quite variable $(110,111)$.

A correlation has been reported between pitting of copper pipe associated with a black cupric oxide surface layer and the presence of certain bacteria (Pseudomonas paucimobilis and Ps. solanacearum) or their polysaccharide $(2,21)$. Davidson et al. (28) correlated the production of acidic metabolic products by a biofilm of the bacterium Acidovorax delafieldii on a copper surface to an increase in copper concentration in the bulk aqueous phase (i.e., corrosion). The amount of extractable, surfaceassociated copper was positively correlated with both protein and carbohydrate concentrations in the biofilm. Bremer and Geesey (17) showed a correlation between acidic polysaccharide accumulation in bacterial biofilms on copper films and initiation of copper film dissolution.

Little et al. (68) used scanning vibrating electrode microscopy, employing a $20 \mu \mathrm{m}$ microprobe, to demonstrate the formation of localized anodic areas on copper coupons in the presence of the marine bacterium Oceanospirillum and its exopolymer. Fluorescence microscopy with the Live/Dead Backlight Viability $\mathrm{Kit}^{\circledR}$ showed that the anodic areas corresponded to those with higher bacterial densities, 
but the sequence in which the surface changes occurred was not determined.

The relationship between pitting propensity and the properties of biofilm polymers has been investigated by Siedlarek et al. (100). Cyclic voltammetry showed that the artificial biofilms formed by the model polysaccharides, xanthan, alginate and agarose, displayed cation selectivity and exerted considerable influence on the corrosion reaction(s) of a copper surface in contact with an aqueous phase, particularly at the sites where solid corrosion products were precipitated $(100,113)$. A physicochemical model was developed to describe the pitting corrosion observed on copper piping of potable water systems. The model takes into account membrane properties and heterogeneity, and the distribution of exopolymers on the surface of the pipes (113).

\section{Acid-Producing Bacteria (APB)}

Bacteria can produce copious quantities of either inorganic or organic acids as by-products of metabolism. Acidophilic sulfur oxidizing bacteria (SOB), such as Thiobacillus spp., oxidize reduced forms of sulfur to sulfate. These microbes can cause severe corrosion damage to mining equipment. Organic acid-producing bacteria were suggested as the primary cause in a case of carbon steel corrosion in an electric power station; they were the only group of culturable microorganisms whose abundance was correlated positively with corrosion (103). Acetic, formic and lactic acids are common metabolic by-products of APB. Little et al. (62) showed that an aerobic, acetic acid-producing bacterium accelerated the corrosion of cathodically protected stainless steel. Protective calcium-rich deposits formed during cathodic polarization were destabilized or dissolved by artificially applied acetic acid. Little et al. (65) also provided examples of acids synthesized in the Krebs Cycle, common to most aerobic microorganisms, which can contribute to MIC; however, the intermediate metabolites of the Krebs cycle are generally retained within the microbial cells. A culture of Streptococcus released high amounts of copper from a Cu-Zn-Al-Ni odontological alloy (91), showing that lactic acid released by these bacteria can participate in corrosion reactions.

The mechanism of action of acids on corrosion of mild steel is well established in the metallurgical literature (99), but the acids produced and their concentrations are rarely monitored under MIC conditions. Acids produced by slime-producing microorganisms are concentrated at the metal surface; hence the bulk aqueous phase $\mathrm{pH}$ (most frequently measured by investigators) may be an entirely irrelevant parameter. Microsensors have been used to probe the $\mathrm{pH}$ gradients within $1 \mathrm{~mm}$ thick microbial biofilms growing on corroded mild steel surfaces (59). $\mathrm{pH}$ values increased from 7.5 at the bulk fluidbiofilm interface to 9.5 at the metal surface in cathodic areas and ranged from 5 to 7 at the surface of the tubercle in anodic areas.

Slime-producing microorganisms that excrete acidic extracellular polysaccharides during biofilm formation on metal surfaces may influence corrosion. Carboxylic acid groups of matrix polysaccharides such as alginic acid, produced by the biofilm-forming bacterium Pseudomonas aeruginosa, have been calculated to be of the order of 6 Angstroms apart, and thus highly concentrated at the metal-biofilm interface (52). It is virtually impossible to concentrate dissolved low molecular weight acids to such a high level. These ionizable acidic groups may therefore be very important in corrosion when the $\mathrm{pH}$ of the biofilm is low.

\section{Fungi}

Fungi are well-known to produce organic acids, and are therefore capable of contributing to MIC. Much of the published work on biocorrosion of aluminum and its alloys has implicated fungal contaminants of jet fuel, Hormoconis (previously classified as Cladosporium) resinae, Aspergillus spp., Penicillium spp. and Fusarium spp. The fungus $H$. resinae utilizes the hydrocarbons of fuel to produce organic acids. Surfaces in contact with the aqueous phase of fuel-water mixtures and sediments are common sites of attack (95). The large quantities of organic acid by-products excreted by this fungus selectively dissolve or chelate the copper, zinc and iron at the grain boundaries of aircraft aluminum alloys, forming pits which persist under the anaerobic conditions established under the fungal mat. Growth of this and other fungi in diesel fuel storage tanks can produce large quantities of biomass (13) and this may provoke crevice attack on the metal (37). Grease-coated wire rope wound on wooden spools stored in a humid environment has been reported to be corroded by Aspergillus niger and Penicillium spp. Both fungal species are 
known to produce citric acid (67), which may be involved in the attack.

Iron-reducing fungi have been isolated from tubercles in a water distribution system (36), suggesting another mechanism whereby corrosion may be accelerated by this group of microorganisms.

\section{Microbial consortia}

Microorganisms are almost never found in nature as pure species and, while laboratory studies on isolated pure cultures are essential to the understanding of MIC, the role of microbial consortia is becoming increasingly recognized.

The acids produced by APB serve as nutrients for SRB and methanogens and it has been suggested that SRB proliferate at sites of corrosion due to the activities of APB (103). Dowling et al. (33) compared corrosion of $\mathrm{C} 1020$ pipeline steel in the presence and absence of the acetogenic bacterium, Eubacterium limosum, and mixed SRB populations (Desulfovibrio sp. and Desulfobacter spp.). E. limosum alone had little effect on the corrosion rate compared to sterile controls, but when inoculated with the Desulfovibrio $s p$., a significantly higher rate of corrosion was found. It was proposed that by-products of E. limosum supported Desulfovibrio sp. growth and sulfide production.

The interactions between microbial species are complex. Gaylarde and Johnston (42) showed that anaerobic corrosion of mild steel was enhanced in pure cultures of Desulfovibrio vulgaris, but reduced to below control levels by pure Vibrio anguillarum; in the presence of both species, corrosion rates were the highest of all. On the other hand, a second facultatively anaerobic bacterium, probably of the genus Citrobacter, had little effect on corrosion rates, except in triple cultures, where it apparently modified the action of the other species (Fig. 2). It was suggested that $V$. anguillarum produced a stronglybound, protective film on the metal surface in pure cultures, but that this film incorporated SRB cells when $D$. vulgaris was present, turning it into a highly aggressive biofilm. The incorporation of the third organism into this biofilm would reduce the SRB population, thereby ameliorating its effects.

Consortia of MDB and SRB often exist as biofilms on corroding metal surfaces. It has been proposed that oxygen consumption by MDB creates redox conditions favorable for the growth of SRB (106) and the joint action of MDB and SRB may

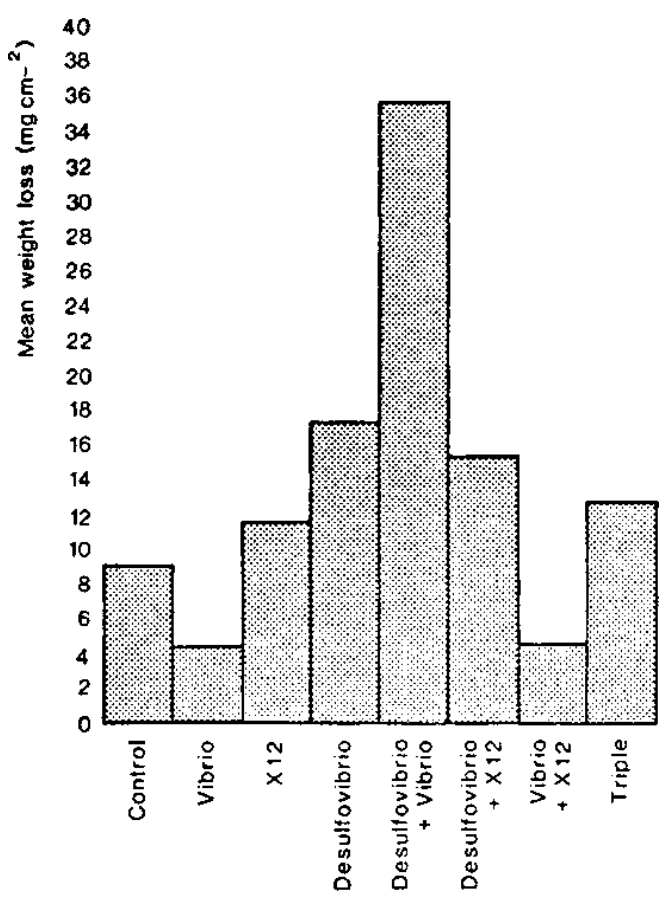

Figure 2 - Weight loss of mild steel exposed to pure and mixed bacterial cultures after 3 weeks incubation in Postgate Medium B at room temperature (approx. $22{ }^{\circ} \mathrm{C}$ ). X12 = presumptive Citrobacter.

promote the breakdown of the passive film on stainless steel (61).

A bacterial consortium was shown to be necessary for the maintenance of corrosion current of pitted 304L stainless steel in seawater under anaerobic conditions (3). SRB were present on the cathode, leading to high charge transfer resistance, while the consortium on the anode decreased charge transfer resistance. These results were stated to support the involvement of cathodic depolarization in the anaerobic biocorrosion of stainless steel.

A number of microorganisms isolated from corroding copper pipework in Auckland, New Zealand, attached to and grew on copper surfaces in a simulated potable water medium (114). The four most numerous culturable bacterial species were identified by $16 \mathrm{~s}$ rRNA gene sequence analysis as Sphingomonas capsulata (European Bioinformatics Institutes (EMBL) Nucleotide sequence database \# AJ223450), Staphylococcus warneri (EMBL \#AJ223451), Erythrobacter longus (EMBL \# AJ223452) and Methylobacterium sp. (EMBL \#AJ223453). A yeast, identified as a Candida sp., was also recovered from the copper surface. Biofilms 
containing these isolates were shown to promote release of copper corrosion by-products in subsequent laboratory reactor experiments (114).

\section{Techniques for the Study of Biocorrosion}

The forms of corrosion which can be promoted by the interaction of microorganisms with metals are numerous, including general pitting, crevice attack, stress corrosion cracking, enhancement of corrosionfatigue, intergranular stress cracking and hydrogen embrittlement and cracking. Most cases of MIC are associated with localized attack (Fig. 3). The complexity of MIC reactions means that a broad range of techniques must be employed to relate the corrosion processes to the microbial activities at surfaces.

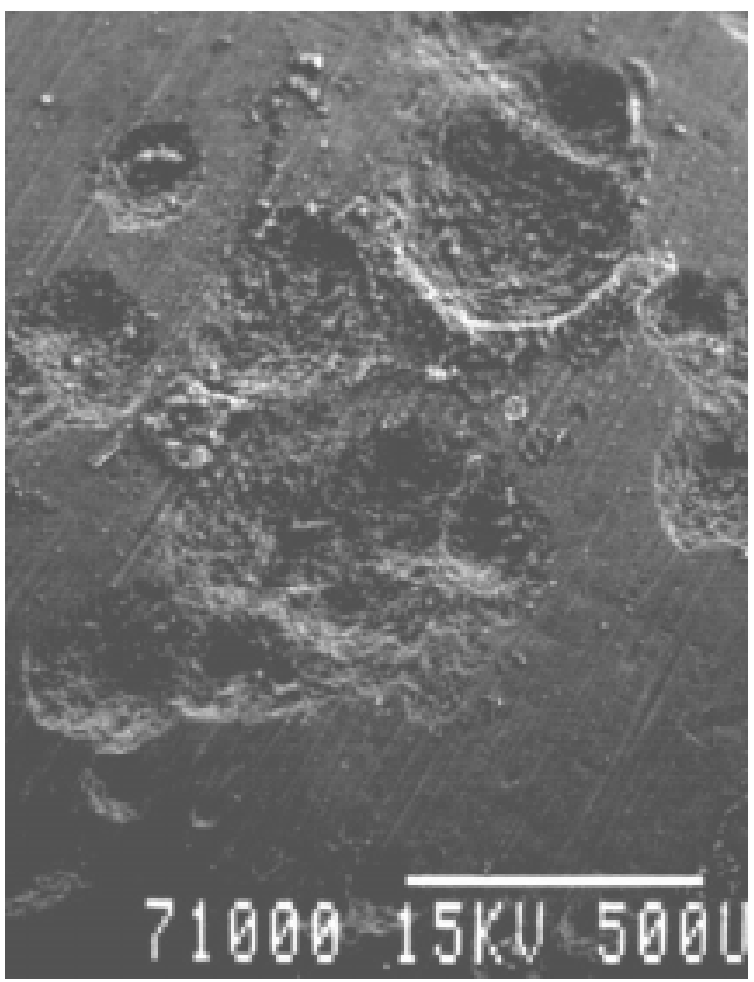

Figure 3 - SEM micrograph of mild steel surface, showing localized attack, following exposure to mixed population of Pseudomonas spp and sulfate-reducing bacteria.

\section{Qualitative and semi-quantitative evaluation of MIC}

The contribution of microorganisms to corrosion has been assessed using a variety of optical and electron microscopy techniques. Recently, environmental scanning electron microscopy (ESEM), atomic force microscopy (AFM; Fig. 4) and confocal laser scanning microscopy (CLSM) have been employed to study biofilms and biocorrosion phenomena (10). Microscope techniques provide information about the morphology of microbial cells and colonies, their distribution on the surface, the presence of EPS (Figs. 1 and 4) and the nature of corrosion products (crystalline or amorphous; Fig. $5 \mathrm{a}$ and $\mathrm{b}$ ). They can also reveal the type of attack (e.g. pitting or uniform corrosion) by visualizing changes in microstructure and surface features after removal of the biofilm and corrosion products (Fig. 6). CLSM and AFM allow the examination of hydrated biofilms and yield clean, three-dimensional images of living biofilms in real time. CLSM has shown that 75 to $95 \%$ of the volume of bacterial biofilms is occupied by the matrix, and cells may be concentrated in only $5-25 \%$ of the lower or upper layers (24). ESEM studies of biocorrosion and protective coatings have also been reported $(54,112)$. However, the detection of microorganisms, in itself, should not be the sole basis on which their involvement in the corrosion process is implicated. To confirm MIC, specific activities of the microbes at the site where corrosion is occurring should be demonstrated. Microscopic and culture techniques alone rarely provide such evidence.

Chemical spectroscopy at surfaces offers information on the nature of the accumulated

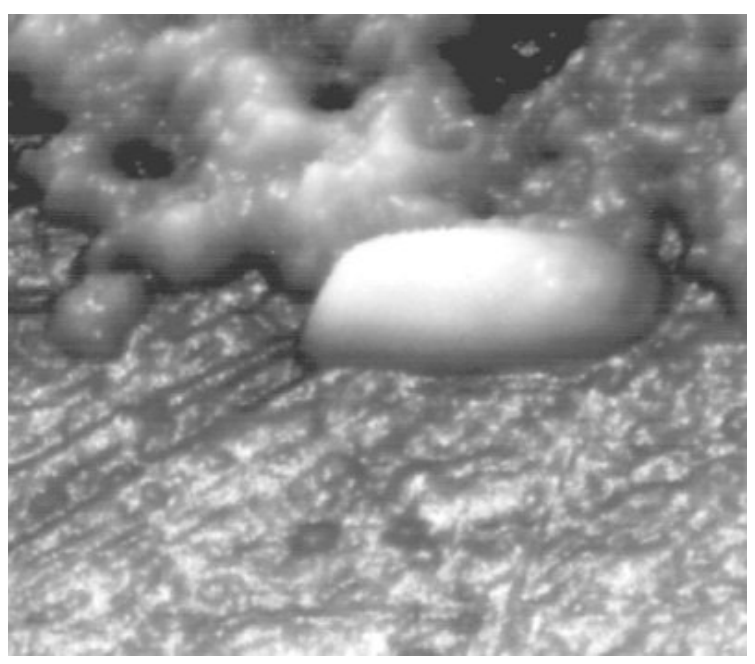

Figure 4 - Atomic force microscopy image of a single bacterial cell and its associated EPS on a surface of AISI 316 stainless steel. 


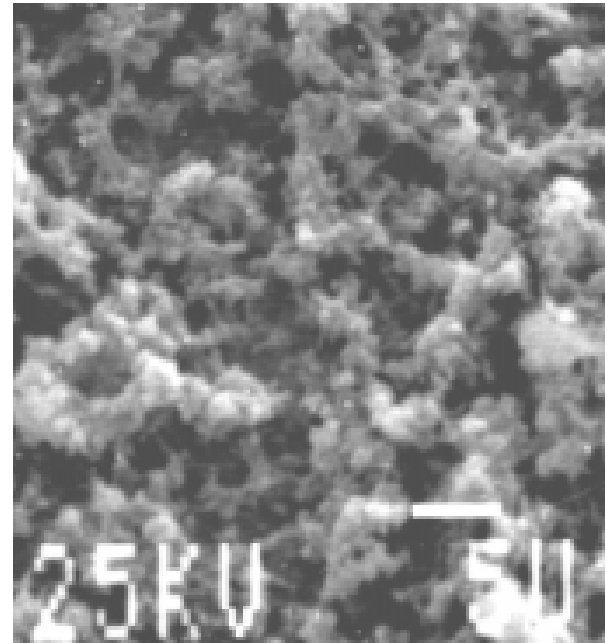

A the oxidation state of the elements present, facilitating prediction of corrosion product chemistry and, to some extent, chemistry of the associated microbial biofilm (90). It has also been used to determine the influence of a biofilm on the structure of the passive layer formed on AIS 316 stainless steel (11). AES and XPS are suitable only for evaluating the composition of thin scaling deposits, but laser Raman spectroscopy (LRS), coupled with optical microscopy, can be used to analyze thicker (above

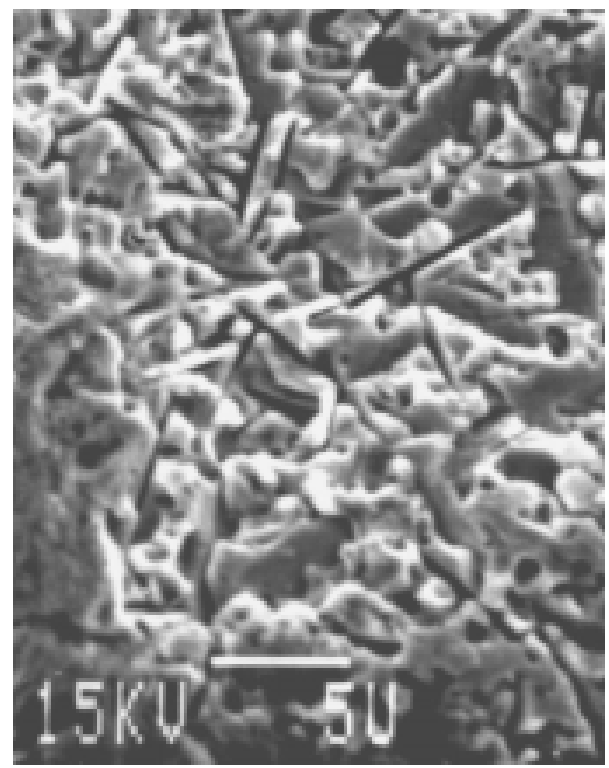

Figure 5 - SEM micrograph of amorphous (a) and crystalline (b) biocorrosion products on a mild steel surface.

corrosion products, which can be specifically associated with microbial activities. Spatially resolved surface chemistry obtained by spectroscopy must be related to the spatially resolved microbiology at the same location. Surface chemical analysis provides information on the chemical composition of the corrosion products and microbiological deposits, and thus gives the opportunity to gain insight into the electrochemical reactions involved in the corrosion process. X-ray diffraction (XRD) and energy dispersive X-ray analysis (EDAX) have been widely used to obtain elemental information on corrosion products on metal surfaces (82). Auger electron spectroscopy (AES) allows mapping of corrosion products across a metal surface that has experienced localized attack. It has been used to investigate biocorrosion in condenser tubes (22). X-ray photoelectron spectroscopy (XPS) can resolve

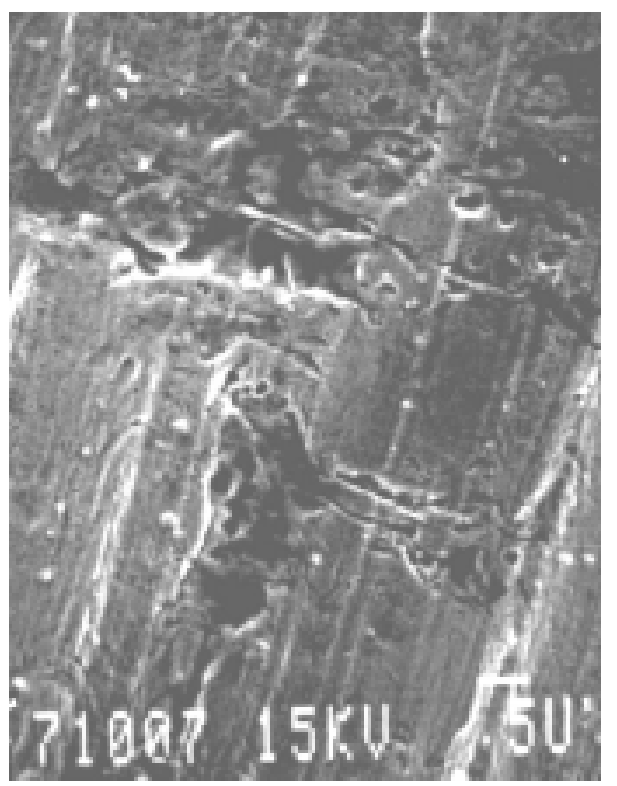

Figure 6 - SEM image of a mild steel surface after the removal of bacterial biofilm, revealing changes in surface characteristics. 
$1 \mu \mathrm{m})$ deposits (101) and offers an interesting technique for future biocorrosion studies. Mössbauer spectroscopy can be applied to iron-containing compounds. It has been used to detect "green rust 2" among corrosion products of steel exposed to marine sediments containing SRB (88) and subsequent, controlled laboratory studies showed that this corrosion product was exclusively associated with SRB-induced corrosion (83).

Machado et al. (80) used XRD, Mössbauer spectrophotometry and EDAX to show that the surface film formed on mild steel in the presence of a consortium of $H$. resinae and SRB was mainly composed of magnetite $\left(\mathrm{Fe}_{3} \mathrm{O}_{4}\right)$, maghemite $\left(\gamma-\mathrm{Fe}_{2} \mathrm{O}_{3}\right)$, goethite $(\alpha-\mathrm{FeOOH})$ and lepidocrocite $(\gamma-\mathrm{FeOOH})$. Under the experimental conditions used, this film was protective.

The presence of mackinawite and greigite among corrosion products of iron is generally evidence that SRB participated in the corrosion reaction $(51,77$, 79). Under alternating reducing and oxidizing conditions, the partially oxidized iron oxide magnetite is often produced, along with lepidocrocite and goethite (51). These mineral signatures of MIC have been detected, using XRD and EDAX, as corrosion products on many oil and gas pipeline systems (51). Amorphous iron sulfide is also often detected by EDAX at pipeline corrosion sites. Little is known about its subsequent crystallization, although biomineralization around SRB colonies or within biofilms may be a key process.

Characteristic copper sulfides, chalcocite $\left(\mathrm{Cu}_{2} \mathrm{~S}\right)$, covellite $\left(\mathrm{CuS}_{1-\mathrm{x}}\right)$ and djurleite $\left(\mathrm{Cu}_{31} \mathrm{~S}_{16}\right)$ are formed during corrosion of copper and its alloys in the presence of SRB $(77,78)$. The formation of thick, non-adherent layers of chalcocite or the formation of hexagonal chalcocite is indicative of SRB-induced corrosion of copper and copper alloys.

\section{Quantitative assessment of MIC}

Corrosion rates are commonly determined by electrochemical methods, such as potentiodynamic polarization, zero-resistance ammetry, electrochemical impedance spectroscopy (EIS) and electrochemical noise (ECN), in addition to classical weight loss measurements. A detailed review of these techniques is given by Mansfield and Little (81).

Microsensors, which are largely electrochemically-based, offer the resolution that is needed for studying the localized corrosion processes induced by microorganisms. They have been applied to characterize the chemical gradients within biofilms on corroding metal surfaces. Microsensors were employed to show depletion of oxygen within tubercles formed on corroding mild steel surfaces (59) and at anodic areas of the surface covered by a $1 \mathrm{~mm}$ thick biofilm. This spatially resolved surface chemical approach enabled these investigators to demonstrate the existence of differential oxygen concentration cells and their role as the driving force for the corrosion reaction.

Attenuated total reflectance Fourier transform infrared spectroscopy (ATR/FTIR) was used to quantify the rate of corrosion of a thin metal film deposited as an internal reflectance element, which is exposed to either flowing or stagnant aqueous media. The method is based on the observation that water absorbance in the infrared increases as the thin film decreases in thickness as a result of corrosion. Changes in film thickness corresponding to a few atomic layers can be detected and the measurements can be obtained non-destructively in real time. Quantitative changes in water absorbance are expressed as a corrosion rate. ATR/FTIR has been used to demonstrate the participation of a microbial biofilm in the localized attack of copper films and the relation between onset of corrosion and the production of polysaccharide during biofilm formation (17). It has also been used to demonstrate the influence of the exopolysaccharide produced by the marine bacterium Pseudoalteromonas (Pseudomonas) atlantica on the corrosion of copper (53).

It is indisputable that both qualitative and quantitative approaches are necessary to investigate the role of microorganisms in corrosion processes. Increasingly sophisticated techniques are being employed to study corrosion, microbial activities in biofilms and the types of microorganisms present. The information from the use of molecular gene probes, demonstrating that the majority of microorganisms in the natural environment are unculturable, means that our understanding of MIC is extremely limited. This multi-disciplinary subject, with its important practical applications, is certain to be an area of intense research activity in the future.

\section{ACKNOWLEDGMENT}

We wish to thank CNPq for a grant (Pesquisador Visitante) to I B Beech. 


\section{RESUMO}

\section{Avanços recentes no estudo da biocorrosão: uma revisão}

Processos de biocorrosão na superfície de metais são associados com microrganismos ou com os seus produtos metabólicos, tais como: enzimas, exopolímeros, ácidos orgânicos e inorgânicos, e compostos voláteis como amônio ou sulfeto de hidrogênio. Todos estes produtos podem afetar reações catódicas e/ou anódicas, alterando processos eletroquímicos na interface biofilme/metal. Esta revisão discute diversos mecanismos de biocorrosão causados pelos diferentes atividades fisiológicas associadas com microrganismos e os conhecimentos mais recentes. Estudos modernos da corrosão microbiologicamente influenciada focalizam problemas em ligas de ferro e de cobre. Microrganismos especialmente enfocados são as bactérias redutoras de sulfato e bactérias que depositam metais, destacando aquelas que depositam manganês. A importância de consórcios microbianos e o papel de substâncias poliméricas extracelulares na biocorrosão são enfatizados nesta revisão. Considera-se a contribuição de técnicas analíticas modernas, tais como microscopia de força atómica, espectroscopia Auger, espectroscopia de raio-X, espectroscopia Mössbauer, espectroscopia de infravermelho de reflectância total com transformação de Fourier e microsensores.

Palavras-chave: Aço, bactérias redutoras de sulfato, espectroscopia de superfície, cobre, corrosão.

\section{REFERENCES}

1. Abdollahi, H.; Wimpenny, J.W.T. Effects of oxygen on the growth of Desulfovibrio desulfuricans. J. Gen. Microbiol., 136: 1025-1030, 1990

2. Angell, P.; Campbell, H.S.; Chamberlain, A.H.L. International Copper Association (ICA), Project $N^{\circ} 405$, Interim Report, 1990.

3. Angell, P.; Luo, J.-S.; White, D.C. Microbially sustained pitting corrosion of 304 stainless steel in anaerobic seawater. Corr. Sci., 37: 1085-1096, 1995.

4. Bak, F.; Cypionka, H.A. novel type of energy metabolism involving fermentation of inorganic sulfur compounds. Nature, 326: 891-892, 1987.

5. Barton, L.L. (ed.) Sulfate-reducing bacteria. Plenum Press, New York, 1984
6. Beech, I. B.; Cheung, C.W.S.; Chan, C.S.P.; Hill, M.A.; Franco, R.; Lino A.R. Study of parameters implicated in the biodeterioration of mild steel in the presence of different species of sulphate-reducing bacteria. Internat. Biodet. Biodeg., 34: 289-303, 1994.

7. Beech, I.B.; Cheung, C.W.S. Interactions of exopolymers produced by sulphate-reducing bacteria with metal ions. Internat. Biodet. Biodeg., 35: 59-72, 1995.

8. Beech, I.B.; Zinkevich, V.; Tapper, R.; Gubner, R.; Avci, R. The interaction of exopolymers produced by marine sulphatereducing bacteria with iron, in: W. Sand (ed.), Biodeterioration and Biodegradation, 10th International Biodeterioration and Biodegradation Symposium, Hamburg, Dechema Monographs vol.133, Frankfurt, 1996, pp. 333-338.

9. Beech, I.B.; Zinkevich, V.; Tapper, R.; Gubner, R. The direct involvement of extracellular compounds from a marine sulphate-reducing bacterium in deterioration of steel. Geomicrobiology J., 15: 119-132, 1998.

10. Beech, I.B.; Tapper, R.; Gubner, R. Microscopy methods for studying biofilms. In: Biofilms: recent advances in their study and control. L.V. Evans (ed.), Harwood Academic Publ. 1999. In press.

11. Beech, I.B.; Gubner, R.; Zinkevich, V.; Hanjangsit, L.; Avci, $\mathrm{R}$. The effect of Pseudomonas NCIMB biofilm on the formation of passive layer on AISI 316 stainless steel. Corrosion 99, NACE, Houston Tx., Paper No 185, 1999a.

12. Beech, I.B., Zinkevich, V., Tapper, R. and Avci, R. Study of the interaction of exopolymers produced by sulphate-reducing bacteria with iron using X-ray Photoelectron Spectroscopy and Time-of-Flight Secondary Ionisation Mass Spectrometry. J. Microbiol. Meths. 36, 3-10, 1999.

13. Bento, F.M.; Gaylarde, C. Microbial contamination of stored diesel oil in Brazil. Rev. Microbiol. 27:192-196, 1996.

14. Bibb, M. Bacterial corrosion in the South African power industry. In S.C. Dexter (ed.) Biologically Induced Corrosion, National Association of Corrosion Engineers, Houston, TX, 1986, pp. 96-101.

15. Booth, G.H. Sulphur bacteria in relation to corrosion. J. Appl. Bacteriol., 27: 174-181: 1964.

16. Borenstein, S.W. Microbially influenced corrosion handbook. Woodhead, Cambridge, UK, 1994.

17. Bremer, P.J.; Geesey, G.G. Laboratory-based model of microbially induced corrosion of copper. Appl. Environ. Microbiol., 57: 1956-1962, 1991.

18. Brennenstuhl, A.M.; Doherty, P.E. The economic impact of microbiologically influenced corrosion at Ontario Hydro's nuclear plants. In: N.J. Dowling, M.W. Mittelman and J.C. Danko (eds.), Microbiologically Influenced Corrosion and Biodeterioration, University of Tennessee, Knoxville, TN, 1990. pp. 7/5-7/10.

19. Bryant R.D.; Jansen, W.; Bovin, J.; Laishley, E.J.; Costerton, J.W. Effect of hydrogenase and mixed sulfate reducing bacterial populations on the corrosion of steel. Appl. Environ. Microbiol., 57: 2804-2809, 1991.

20. Bryant, R.D.; Kloeke, F.V.O.; Laishley, E.J. Regulation of the periplasmic [Fe] hydrogenase by ferrous iron in Desulfovibrio vulgaris Hildenborough. Appl. Environ. Microbiol., 59: 491-495, 1993.

21. Chamberlain, A.H.L.; Angell, P.; Campbell, H.S. Staining procedures for characterising biofilms in corrosion investigations. Br. Corros. J., 23: 197-199, 1988. 
22. Chen, J-R.; Chyou, S.-D.; Lew, S.-I.; Huang, C.-J.; Fang, C.-S.; Tse, W.-S. Investigation of the biological corrosion of condenser tubes by scanning Auger microprobe techniques. Appl. Surf. Sci., 33/34: 212-219, 1988.

23. Cheung, C.W.S.; Beech, I.B. The use of biocides to control sulphate-reducing bacteria in biofilms on mild steel surfaces. Biofouling, 9: 231-249, 1996.

24. Costerton, J.W. Structure of Biofilms. In: Biofouling and Biocorrosion in Industrial Water Systems. Lewis, Boca Raton, Fla., 1994, p. 1.

25. Cragnolino, G.; Tuovinen, O.H. The role of sulfate-reducing and sulfur-oxidising bacteria in the localized corrosion of iron-based alloys, A review. Internat. Biodet., 20: 9-18, 1984.

26. Crolet, J.-L. From biology and corrosion to biocorrosion, Oceanol. Acta, 15: 87-94, 1992.

27. Daumas, S.; Massiani, Y.; J. Crousier. Microbiological battery induced by-sulphate-reducing bacteria. Corr. Sci., 28: 1041-1050, 1988.

28. Davidson, D.; Beheshti, B.; Mittelman, M.W. Effects of Arthrobacter sp., Acidovorax delafieldii and Bacillus megatherium colonization on copper solvency in a laboratory reactor. Biofoul., 9: 279-292, 1996.

29. Davies, D.G.; Parsek, M.R.; Pearson, J.P.; Iglewski, B.H.; Costerton, J.W.; Greenberg, E.P. The involvement of cell-tocell signals in the development of a bacterial biofilm. Science, 280, 295-298. 1998.

30. Dickinson,W.; Lewandowski, Z. Manganese biofouling and corrosion behaviour of stainless steel. Biofouling, 10: 79-93, 1996.

31. Dickinson, W.F.; Caccavo, J.R.; Olesen, B.; Lewandowski, Z. Ennoblement of stainless steel by the manganesedepositing bacterium Leptothriix discophora. Appl. Environm. Microbiol., 63: 2502-2506, 1997.

32. Dilling, W.; Cypionka, H. Aerobic respiration in sulfatereducing bacteria. FEMS Micriobiol. Lett., 71: 123-128, 1990.

33. Dowling, N.J.E.; Brooks, S.A.; Phelps, T.J.; White, D.C. Effects of selection and fate of substrates supplied to anaerobic bacteria involved in the corrosion of pipe-line steel. J. Ind. Microbiol., 10: 207-215, 1992.

34. Dowling, N.J.E.; Mittelman, M.W.; White, D.C. The role of consortia in micobially influenced corrosion. In: J.G. Zeikus, (ed.), Mixed Cultures in Biotechnology, McGraw Hill, New York, 1991, pp. 341-372.

35. Edyvean, R.G.J.; Benson, J.; Thomas, C.J.; Beech, I.B.; Videla, H. Biological influences on hydrogen effects in steel in seawater. Mat. Perform., 37: 40-44, 1998

36. Emde, K.M.E.; Smith, D.W.; Facey, R. Initial investigation of microbially influenced corrosion (MIC) in a low temperature water distribution system. Water-Research, 26: 169-175, 1992.

37. Englert, G.E.; Müller, I.L. Corrosion behavior of a martensitic steel in diesel oil. In: $L A B S$ 3, eds. C.C. Gaylarde, T.C.P. Barbosa and N.H. Gabilan, The British Phycological Society, UK, 1998, Paper no 24.

38. Fischer, W.R.; Hänssel, I.; Paradies, H.H. First results of microbial induced corrosion on copper pipes. In: Microbial Corrosion-1, C.A.C. Sequeira and A.K. Tiller (eds), Elsevier Applied Sciences, London, 1988, pp. 300-327.

39. Fischer, W.R.; Paradies, H.H.; Wagner, D.; Hän el, I. Copper deterioration in a water distribution system of a county hospital in Germany caused by microbially induced corrosion. 1. Description of the problem. Werkst. Korros., 43: 56-62. 1992.
40. Flemming, H.-C. Biofouling and microbiologically influenced corrosion (MIC)-an economical and technical overview. In: E. Heitz, W. Sand and H.-C. Flemming (eds.) Microbial Deterioration of Materials, Springer, Heidelberg, 1996, pp. 5-14.

41. Gaylarde, C.C.; Johnston, J.M. The effect of Vibrio anguillarum on the anaerobic corrosion of mild steel by Desulfovibrio vulgaris. Internat. Biodeter. Bull., 18: 111-116, 1982.

42. Gaylarde, C.C.; Johnston, J.M. Anaerobic metal corrosion in cultures of bacteria from estuarine sediments. In: S.C. Dexter (ed), Biologically Induced Corrosion, NACE-8, Houston, TX, 1986, pp. 137-143.

43. Gounot, A.M. Microbial oxidation and reduction of manganese: Consequences in groundwater and applications. FEMS Microbiol. Rev., 14: 339-350, 1994.

44. Gubner, R. J.; Breakspear, S.; Beech, I. B. The effect of iron and dissolved oxygen level on the biocorrosion of piling grade carbon steel. LABS 3, eds. C.C. Gaylarde, T.C.P. Barbosa and N.H. Gabilan, The British Phycological Society, UK, 1998, Paper $n^{\circ} 41$.

45. Hamilton, W.A. Sulphate reducing bacteria and anaerobic corrosion. Ann. Rev. Microbiol., 39: 195-217, 1985.

46. Hamilton, W.A. Metabolic interaction and environmental microniches: implications for the modeling of biofilm process. In: G.G. Geesey, Z. Lewandowsky and H.-C. Flemming (eds.) Biofouling and Biocorrosion in Industrial Water Systems, 2nd edition, CRC Press Inc., Boca Raton, FL, 1994, pp. 27-36.

47. Hamilton, W.A. Sulphate-reducing bacteria: physiology determines their environmental impact. Geomicrobiol. J., 15: 19-28, 1998.

48. Hardy, J.A.; Hamilton, W.A. The oxygen tolerance of sulfatereducing bacteria isolated from the North Sea waters. Curr. Microbiol., 6: 259-262, 1981.

49. Iverson, I.P.; Olson, G.J. Anaerobic corrosion by sulfatereducing bacteria due to highly reactive volatile phosphorus compound. In: Microbial Corrosion, Metals Society, London, 1983, pp. 46-53.

50. Jack, R.F.; Ringelberg, D.B.; White, D.C. Differential corrosion rates of carbin steel by combinations of Bacillus sp., Hafnia alvei, and Desulfovibrio gigas established by phospholipid analysis of electrode biofilm. Corr. Sci., 33: 1843-1853, 1992.

51. Jack, T.R.; Wilmott, M.J.; Sutherby, R.L. Indicator minerals formed during external corrosion of line pipe. Mat. Perform., 34: 19-22, 1995.

52. Jang, L.K.; Quintero, E.; Gordon, G.; Rohricht, M.; Geesey, G.G. The osmotic coefficients of the sodium form of some polymers of biological origin. Biopolymers, 28: 1485-1489, 1989.

53. Jolley, J.G.; Geesey, G.G.; Hankins, M.R.; Wright, R.B.; Wichlacz, P.L. In situ, real time FT- IR/CIR/ATR study of the biocorrosion of copper by gum arabic, alginic acid, bacterial culture supernatant and Pseudomonas atlantica exopolymer. Appl. Spectrosc., 43:1062-1067, 1989.

54. Jones-Meehan, J.; Walch, M.; Little, B.J.; Ray, R.I.; Mansfeld, F.B. Biofouling and Biocorrosion in Industrial Water Systems. Lewis, Boca Raton, Fla. 1994, p. 107.

55. Keevil, C.W.; Walker, J.T.; McEvoy, J.; Colbourne, J.S. Detection of biofilms associated with pitting corrosion of copper pipework in Scottish hospitals. In: C.C. Gaylarde and L.H.G. Morton, (eds)., Biocorrosion. Biodeterioration Society Occasional Publication $\mathrm{N}^{\mathrm{o}} 5$, Biodeterioration Society, Lancashire, U.K., 1989. pp. 99-117. 
56. King, R.A.; Wakerley, D.S. Corrosion of mild steel by ferrous sulphide. Br. Corr. J., 8: 41-45, 1973.

57. Kobrin, G. Corrosion by microbiological organisms in natural waters. Mat. Perform., 15: 38-43, 1976.

58. Lai, M.E.; Scotto, V.; Bergel, A. Analytical characterization of natural marine biofilms. $10^{\text {th }}$ Internat. Congress on Marine Corrosion and Fouling, Melbourne, Australia, Feb., 1999. In press.

59. Lee, W.; deBeer, D. Oxygen and pH microprofiles above corroding mild steel covered with a biofilm. Biofouling, 8: 273-280, 1995.

60. Lee, W.; Lewandowski, Z.; Nielsen, P.H.; Hamilton, W.A. Role of sulfate-reducing bacteria in corrosion of mild steel: A review. Biofouling, 8: 165-194, 1995.

61. Lewandowski, Z.; Dickinson, W.; Lee, W. Electrochemical interactions of biofilms with metal surfaces. Wat. Sci. Tech., 36: 295-302, 1997.

62. Little, B.; Wagner, P.; Duquette, D. Microbiologicallyinduced increase in corrosion current density of stainless steel under cathodic protection. Corrosion, 44: 270-274, 1988a.

63. Little, B.; Wagner, P.; Jacobus, J. The impact of sulfatereducing bacteria on welded copper-nickel seawater piping systems. Mat. Perform., 27: 57-61, 1988 b.

64. Little, B.; Wagner, P.; Ray, R.; McNeil, M. Microbiologically influenced corrosion in copper and nickel seawater piping systems. Mar. Technol. Soc. J., 24: 10-17, 1990.

65. Little, B.; Wagner, P.; Mansfeld, F. An overview of microbiologically influenced corrosion. Electrochim. Acta, 37: 2185-2194, 1992.

66. Little, B.; Wagner P. Indicators for sulfate-reducing bacterium microbiologially influenced corrosion. In: G.G. Geesey, Z. Lewandowski and H.-C. Flemming (eds.) Biofouling and Biocorrosion in Industrial Water Systems, 2nd ed, CRC Press Inc., Boca Raton, FL, 1994, pp. 213-230.

67. Little, B.; Ray, R.; Hart, K.; Wagner, P. Fungal-induced corrosion of wire rope. Mater. Perform., 34: 55-58, 1995.

68. Little, B.J.; Wagner, P.A.; Angell, P.; White, D. The role of bacterial exopolymer in marine copper corrosion. LABS2 Biodegradation and Biodeterioration in Latin America, eds. C.C. Gaylarde, E.L.S. de Sa and P.M. Gaylarde, UNEP/ UNESCO/ICRO-FEPAGRO/UFRGS, Brazil, 1996, pp. 98-100.

69. Little, B. J.; Wagner, P.; Mansfeld, F. Microbiological testing In Microbiologically Influenced Corrosion. Corrosion testing made easy, vol.5, NACE International, Houston, TX, 1997a, pp. 29-52.

70. Little, B.J.; Wagner, P.; Hart, K.; Ray, R.; Lavoie, D.; Nealson, K.; Aguilar, C. The role of metal-reducing bacteria in microbiologically influenced corrosion. In: Proc. NACE Corrosion '97, NACE International, Houston, TX, Paper $\mathrm{N}^{\mathrm{o}}$ 215, $1997 \mathrm{~b}$.

71. Little, B.J.; Wagner, P.A.; Lewandowski, Z. The relationship between biomineralization and microbiologically influenced corrosion. $L A B S$ 3, eds. C.C. Gaylarde, T.C.P. Barbosa and N.H. Gabilan, The British Phycological Society, UK, 1998, Paper $\mathrm{n}^{\mathrm{o}} 50$.

72. Little, B.J.; Ray, R.I.; Jones-Meehan, J. Interpreting spatial relationships between marine bacteria and localized corrosion on steels. $1^{\text {th }}$ Internat. Congress on Marine Corrosion and Fouling, Melbourne, Australia, Feb., 1999. In press.
73. Little, J.; Edyvena, R.G.J. The influence of marine fouling on hydrogen permeation through steels. Proc. NSF CONICET workshop Biocorrosion and Biofouling, eds. H.A. Videla, Z. Lewandowski and R.W. Lutey, Buckman Intl., Memphis, 1992.

74. Lovley, D.R.; Philips, E.J.P. Novel processes for anaerobic sulfate production from elemental sulfur by sulfatereducing bacteria. Appl. Environ. Microbiol., 60: 2394-2399, 1994.

75. Lutey, R.W. Identification and detection of microbiologically influenced corrosion. In: H.A. Videla, Z. Lewandowski; R. Lutey (eds), Proc. NSF-CONICET Workshop Biocorrosion and Biofouling, Metal/Microbe Interactions, November 92, Mar del Plata, Argentina, Buckman Laboratories International, Inc., Memphis, TN, 1992, pp. 146-158.

76. McEvoy, J.; Colbourne, J.S. Glasgow hospital survey pitting corrosion of copper tube. Report to the International Copper Research Association, New York, 1988.

77. McNeil, M.B.; Jones, J.M.; Little, B.J. Mineralogical fingerprinting for corrosion processes induced by sulfate reducing bacteria. Paper $\mathrm{N}^{\circ}$ 580, Proc. NACE Corrosion '91, NACE, Houston, TX, 1991a.

78. McNeil, M.B.; Jones, J.M.; Little, B.J. Production of sulfide minerals by sulfate-reducing bacteria during microbiologically influenced corrosion of copper. Corrosion, 47: 674-677, 1991b.

79. McNeil, M.B.; Little, B.J. Technical note: Mackinawite formation during microbial corrosion. Corrosion, 46: 599-600, 1990

80. Machado, P.F.L.; Gaylarde, C.C.; Müller, I.L. Microbial influenced corrosion of mild steel ASTM A283 in a marine diesel-aqueous system. $L A B S 3$, eds. C.C. Gaylarde, T.C.P. Barbosa and N.H. Gabilan, The British Phycological Society, UK, 1998, Paper $n^{\circ} 54$.

81. Mansfield, F.; Little, B.J. A critical review of the application of electrochemical techniques to the study of MIC. In: N.J. Dowling, M.W. Mittleman and J.C. Danko, (eds.), Microbially Influenced Corrosion and Biodeterioration, University of Tennessee, Knoxville, TN, 1991, pp. 5/33-5/40.

82. Marquis, F.D.S. Strategy of macro and microanalysis in microbial corrosion. In: C.A.C. Sequeira and A.K. Tiller, (eds.), Microbial Corrosion-1, Elsevier Applied Science, London and New York, 1988, pp. 125-151.

83. Morton, L.H.G.; Greenaway, D.L.A.; Gaylarde, C.C.; Surman, S.B. Consideration of some implications of the resistance of biofilms to biocides. Internat. Biodeter. Biodeg., 41: 247-259, 1998

84. Moulin, J. M.; Marsh, E.; Chao, V.; Karius, R.; Beech, I. B.; Gubner, R.; Raharinaivo, A. Prevention of Accelerated LowWater Corrosion on Steel Piling Structures due to Microbiologically Influenced Corrosion Mechanisms; ECSC final draft report, ECSC agreement $7210-\mathrm{KB} / 503, \mathrm{~KB} / 825$, $\mathrm{KB} / 130, \mathrm{~KB} / 826, \mathrm{~KB} / 337,1998$.

85. Myers, C.; Nealson, K.H. Bacterial manganese reduction and growth with manganese oxide as the sole electron acceptor. Science, 240: 1319-1321, 1988.

86. Obuekwe, C.O.; Westlake, D.W.S.; Plambeck, J.A.; Cook, F.D. Corrosion of mild steel in cultures of ferric iron reducing bacterium isolated from crude oil I. polarization characteristics. Corrosion, 37 (8): 461-467, 1981. 
87. Olowe, A.; Benbouzid-Rollet, N.D.; Génin, J-M.R.; Prieur, D.; Confente, M; Resiak, B. La présance simultanée de rouille verte 2 et de bactéries sulfato- réductrices en corrosion perforante de palplanches en zone portuaire, C.R. Académie des Sciences Paris, t 314, Série II, 1992, pp. 1157-1163.

88. Olowe, A.; R.Génin; J-M.; Guezennec, J. Mössbauer effect study of microbially induced corrosion of steel by sulphate reducing bacteria in marine sediments: role of green rust 2 . In: N.J. Dowling, M.W. Mittleman and J.C. Danko, (eds.), Microbially Influenced Corrosion and Biodeterioration, University of Tennessee, Knoxville, TN, 1991, pp. 5/65-5/72.

89. Paradies, H.H.; Fischer, W.R.; Haenssel, I.; Wagner, D. Characterisation of metal biofilm interactions by extended absorption fine structure spectroscopy. In: C.A.C. Sequeira and A.K. Tiller (eds), Microbial Corrosion-2 European Federation of Corrosion, Publication $\mathrm{N}^{\circ} 8$, The Institute of Materials, 1992, pp 168-188.

90. Pendyala, J.; Avci, R.; Geesey, G.G.; Stoodley, P.; Hamilton, M.; Harkin, G. Chemical effects of biofilm colonization on 304 stainless steel. J. Vac. Sci. Technol., A 14: 1755-1760, 1996.

91. Pizzolitto, E.L.; Pizzolitto, A.C.; Bernardi, A.C.A.; Lochagin, N.; Shuhama, T.; Ito, I.Y.; Guastaldi, A.C. Biocorrosão: estudo in vitro da aderência microbiana, nas ligas metálicas de cobre de aplicação odontológica. $2^{\text {nd }}$ NACE Latin American Region Corrosion Congress September, 1996, Paper LA 96108.

92. Pope, D.H.; Duquette, D.J.; Johannes, A.H.; Wayner, P.C. Microbially influenced corrosion of industrial alloys. Mat. Perform., 23: 14-18, 1984.

93. Postgate, J. R. The Sulphate Reducing Bacteria. 2nd edn. Cambridge University Press, England 1984.

94. Roden, E.E.; Lovley, D.R. Dissimilatory Fe (III) reduction by marine microorganism Desulfuromonas acetooxidans. Appl. Environ. Microbiol., 59: 734-742, 1993.

95. Salvarezza, R.C.; Videla, H.A. Electrochemical behaviour of aluminium in Cladosporium resinae cultures. Biodeterioration 6, S. Barry et al. (Eds.), London, Elsevier, 1986, 1986, pp. 212-217.

96. Schaschl, E. Elemental sulfur as a corrodent in dearated neutral aqueous environments. Mat. Perf., 19: 9-11, 1980.

97. Scotto, V. Microbial and biochemical factors affecting the corrosion behaviour of stainless steels in seawater. A working party report on marine corrosion of stainless steels: chlorination and microbial effects. $\mathrm{N}^{\mathrm{o}} 10$, Institute of Materials, London, 1993, pp. 21-33.

98. Scotto, V.; Alabiso, A.; Beggiato, M.; Marcenaro, G.; Guezenneck, J. Possible chemical and microbiological factors influencing stainless steel MIC in natural seawater. In: C. Christiansen, (ed.), Proceedings of the $5^{\text {th }}$ European Congress on Biotechnology, Copenhagen, Denmark, vol 2, 1990, pp. 866-871.

99. Shreir, L.L. The microbiology of corrosion. In: Corrosion, Vol. 1, J. Wiley, NewYork, 1963. pp. 2.52-2.64.

100. Siedlarek, H.; Wagner, D.; Fischer, W.R.; Paradies, H.H. Microbiologically influenced corrosion of copper: the ionic transport properties of bioploymers. Corr. Sci., 36: 1751-1763, 1994.

101. Singh Raman, R.K.; Gleeson, B.; Young, D.J. Laser Raman spectroscopy: a technique for rapid characterisation of oxide scale layers. Mats. Sci. Technol., 14, 373-376, 1998.
102. Soracco, R.J.; Berger, L.R.; Berger, J.A.; Mayack, L.A.; Pope, D.H.; Wilde, E.W. Microbiologically mediated reduction in the pitting of mild steel overlaid with plywood. Proc. NACE Corrosion '84, NACE, Houston, TX, Paper No 98, 1984.

103. Soracco, R.J.; Pope, D.H.; Eggers, J.M.; Effinger, T.N. Microbiologically influenced corrosion investigations in electric power generating stations. Proc. NACE Corrosion '88, NACE, Houston, TX, Paper No $83,1988$.

104. Tatnall, R. Fundamentals of bacterial induced corrosion. Mat. Perform., 20: 32-38, 1981.

105. Thomas, C.J.; Edyvean, R.G.J.; Brook, R. Biologically enhanced fatigue. Biofouling 1: 65-77, 1988.

106. Videla, H.A.; Characklis, W.G. Biofouling and microbially influenced corrosion. Internat. Biodegrad. Biodeter., 29: 195-207, 1992

107. Videla, H.A.; Mele, M.F.L.; Swords, C.; Edyvean, R.G.J.; Beech, I.B. Comparative study of the corrosion product films formed in biotic and abiotic media. Corrosion 99, NACE, Houston, Tx., Paper No 163, 1999.

108. Videla, H.A.; Swords, C.L.; de Mele, M.; Edyvean, R.G.; Watkins, P.; Beech, I.B. The role of iron in SRB-influenced corrosion of mild steel. Corrosion 98, NACE, Houston, Tx., Paper $\mathrm{N}^{\circ} 289,1998$.

109. von Wolzogen Kuhr, C.A.H.; van der Vlugt, L.S; De grafiteering van Gietijzer als electrobiochemisch Proces in anaerobe Grunden. Water (den Haag) 18: 147-151, 1934.

110. Wagner, D.; Fischer, W.R.; Paradies, H.H. Copper deterioration in a water distribution system of a county hospital in Germany caused by microbially induced corrosion. 2. Simulation of the corrosion process in two test rigs installed in this hospital. Werkst. Korros., 43: 496-500, 1992a.

111. Wagner, D.; Fischer, W.R.; Paradies, H.H. Test methods on microbial induced corrosion in different loops In Proceedings of the 12th Scandinavian Corrosion Congress and Eurocorr, Dipoli, Finland, 1992b, pp. 651-665.

112. Wagner, P.; Little, B.; Ray, R.; Jones-Meehan, J. Investigation of microbiologically influenced corrosion using environmental scanning electron microscopy. Proc. NACE Corrosion '92, NACE, Houston, TX, Paper No 185, 1992.

113. Wagner, D.; Chamberlain, A.H.L.; Fischer, W.R.; Wardell, J.N.; Sequeira, C.A.C. Microbiologically influenced corrosion of copper in potable water installations - a European project review. Mat. Corr., 48; 311-321, 1997.

114. Webster, B.J.; Wells, D.B.; Bremer, P.J. The influence of potable water biofilms on copper corrosion. Proc. NACE Corrosion '96, NACE, Houston, TX, Paper No 294, 1996.

115. Werthén, M.; Hermansson, M.; Elwing, H. In-vitro studies of signal-receptor interactions in bacterial cell density dependent AHL-signaling. $10^{\text {th }}$ Internat. Congress on Marine Corrosion and Fouling, Melbourne, Australia, Feb. 1999. In press.

116. White, D.C.; Nivens, D.E.; Nichols, P.D.; Mikell, A.T.; Kerger, B.D.; Henson, J.M.; Geesey, G.G.; Clarke, K.C. Role of aerobic bacteria and their extracellular polymers in the facilitation of corrosion. In: S.C. Dexter (ed.), Biologically induced corrosion, NACE-8, NACE, Houston, TX, 1986, pp. 233-243.

117. Widdel, F. Microbiology and ecology of sulfate and sulfurreducing bacteria. In: A.J.B. Zehnder (ed.), Biology of Anaerobic Microorganisms, Wiley-Liss, John Wiley and Sons, Inc., New York, 1988, pp. 469-586. 